\title{
Exergetic Evaluation and Optimization of Combined Heat and Power (CHP) Plant of 20.7 MW Capacities under Varying Load Conditions: A Case Study
}

\author{
Shrikant M. Bapat*, Gururaj D. Gokak \\ Department of Mechanical Engineering, KLS, Gogte Institute of Technology, Belagavi, Karnataka 590008, India
}

Corresponding Author Email: smbapat6791@gmail.com

https://doi.org/10.18280/ejee.210212

Received: 15 January 2019

Accepted: 1 April 2019

\author{
Keywords: \\ bagasse, biomass combined heat and \\ power, cogeneration, exergy analysis, \\ sugar
}

\begin{abstract}
The main aim of this paper is to find the effect of power to heat ratio on exergy of Combined Heat and power (CHP) systems used in power plants. Lot of Energy Researchers have investigated and published their work in terms of energy efficiency and its parametric characteristics. But from a thermodynamic point of view it is Exergy and not Energy, which reveals a more meaningful performance of CHP system. In the present work a case study of a CHP system of 20.7 MW capacities is considered and analyzed based on varying load conditions as well as based on Exergy, based on experimental data taken from the plant. For $100 \%$ PLF the optimum value of PHR in terms of TExDR and SSC is 0.546. Exergy analysis reveals that with a decrease in the value of PLF (plant load factor) the optimum value of PHR (power to heat ratio) also reduces.
\end{abstract}

\section{INTRODUCTION}

India is a developing country and with the increase in industrialization coupled with population growth, the demand for power is rapidly increasing. Most of the energy needs are primarily met by fossil fuels. The demand for fossil fuels is ever increasing. But relying completely on energy from fossil fuels is not sustainable because of their regional depletion and associated impact on environment. In this context renewable energy sources play a vital role. The Indian economy is agriculture driven and sugarcane production and usage take a prominent place. Now-a-days the sugar industry is very fortunate of energy crises, as the industry generates its own fuel in the form of bagasse. Steam generated by burning bagasse is used to generate power and the exhaust steam is used for process. In fact, combined heat and power (CHP) or cogeneration systems are used in sugar industry. The principal advantage of CHP systems is their ability to improve the efficiency of fuel use in the production of electrical and thermal energy. The efficiency of energy production in CHP systems can be increased from current levels of $35 \%$ to $55 \%$ in conventional power plants to over $90 \%$ in CHP systems [1]. The evaluation of CHP system is a complex and demanding task. A complete performance analysis is essential both for the power plant constructor and for the end user. Evaluating CHP system based on exergy rather than energy is quite useful. Exergy is useful for improving the efficiency of energy resource use. It quantifies the locations, types and magnitudes of waste and losses. It represents quantitatively the 'useful' energy or ability to do or receive work [2].

A review of previously conducted studies says that a lot has been done regarding CHP systems. The CHP systems are gas turbine, diesel engine and steam turbine based (i.e. depending on the prime mover). F.F. Huang [3] examined three systems using state-of-the-art industrial gas turbines based on first law and second law. It is found that for all the three gas turbine cogeneration systems first law analysis is inadequate. E.
Bilgen [4] analyzed gas turbine based cogeneration system. The components considered for simulation of the results are gas turbine, heat recovery steam generator (HRSG). To simulate these systems, an algorithm has been developed. HRSG is found to be the least efficient component from exergy point of view. Ozgur Balli and Haydar Aras [5], conducted performance evaluation of micro gas turbine (MGTCHP) driven combined heat and power system. The energetic and exergetic efficiencies of the MGTCHP system are $75.99 \%$ and $35.80 \%$ respectively. The exergy consumption occurred highest in the combustion chamber with a value of $129.61 \mathrm{~kW}$. Yilmaz Yoru et al. [6], performed energy and exergy analysis of a gas turbine based CHP system in a ceramic factory. Actual operational data taken over a onemonth period are utilized. The mean energetic and exergetic efficiency values of the CHP system are found to be $82.30 \%$ and $34.70 \%$ respectively. Literature available also reveals that exergy analysis is also performed for diesel engine based CHP systems. Aysegul Abusoglu and Mehmet Kanoglu [7, 8], performed exergy analysis of 25.32 MW diesel engine powered CHP system. Components considered for analyses are compressor, intercooler, waste heat boiler, condenser, pump, diesel engine. The exergy destructions are found to be the highest in the diesel engine. $83.32 \%$ of total exergy destruction in the overall system took place in the diesel engine, while $45.94 \%$ of total fuel exergy got destructed in the diesel engine. The exergy efficiency of diesel engine is found to be $40.4 \%$. A comparison of first law and second law analysis of the diesel engine based CHP system is also done [9]. At full load conditions the first law and second law efficiency of the overall plant is found to be $44.20 \%$ and $40.70 \%$ respectively. Exergetically waste heat boiler is found to be the least efficient component i.e. $11.40 \%$. A comparison of first law and second law analysis of diesel engine based CHP system [9] revealed that exergy analysis is more valuable than energy analysis.

Many scientists and researchers have also carried out exergy 
analysis of steam turbine driven CHP systems. Ozgur balli and co-researchers [10]. Rajkumar [11] performed energy analysis of combined heat performed exergy analysis of CHP system installed in Eskesehir city of turkey. The exergetic efficiency of CHP system is calculated to be $38.16 \%$ with $49880 \mathrm{~kW}$ as electrical product. Highest exergy consumption is found in the combustion chamber. The analysis is performed assuming fixed fuel power and utilized power by the CHP system. M. Siddhartha Bhatt and N. and power systems in cane sugar industry. An analysis is carried out from pure back pressure to pure condensing environment based on standard steam conditions in installations and efficiencies which are currently being achieved experimentally. It is found that as heat to power ratio increases the efficiency of the steam turbine decreases. Also as the fraction of the extracted steam increased the overall efficiency of the plant approaches the boiler efficiency. S.C. Kamate and P.B. Gangawati [12], conducted exergy analysis of back pressure steam turbine (BPST) and condensing extraction steam turbine (CEST) based CHP systems in Indian sugar industries. It is found that boiler is the main contributor towards exergy destruction. It could utilize only $37 \%$ of chemical exergy and nearly $63 \%$ is lost in combustion irreversibility. A comparison of steam turbine, gas turbine and diesel engine based CHP system is also conducted based on exergy [13]. The exergy efficiency for steam turbine, gas turbine and diesel engine based CHP systems is found to be $23.10 \%, 22.60 \%$ and $47.70 \%$ respectively. It is shown clearly that diesel engine based CHP systems should be selected when the thermal demand is small compared to electrical demand.

Based on the literature from the past, it appears that no exegetic studies of CHP system (with steam turbine as prime mover) with variable values of power to heat (PHR) ratio and PLF (plant load factor), is carried out as far as the authors' knowledge is concerned. The technological options available for co-generation in a sugar industry are Extraction cum back pressure route, Extraction cum condensing route and condensing route based on dual fuel system [14]. Usually sugar industry prefers extraction cum condensing route due to its longer operation period even during off-season. Hence in the present context a case study of a CHP system using extraction cum condensing route steam turbine in an Indian sugar industry of 20.7 MW capacities is proposed. Optimization of power generation systems is one of the most important subjects of the energy engineering field. It is well known fact that the power plant is designed to have maximum efficiency at full load (100\% PLF) conditions. But at full load conditions the waste exergy rates emitted to the environment (through flue gases and condensates) would increase. In turn at part load conditions the exergy destruction rates at component level and also the system as whole, would increase but the waste exergy rates emitted to environment would decrease. Thus, operation of the plant is a thermodynamic trade-off between exergy destruction rates and waste exergy rates emitted to environment.

In the present scenario of global warming and greenhouse effect it is very necessary to select environmentally optimal process by using concept of design for environment (DFE) [15]. This paper is an attempt to optimize the case study considered. The specific objectives are:

(1) To analyze exergetically each component of CHP system using actual operational data.

(2) To optimize the operation of CHP system in terms of exergy destruction rates and waste exergy rates in terms of
PHR at various values of PLF.

The actual operational data used is of one-hour interval and for the whole operating/ harvesting season of 170 days from the plant DCS (Distributed control systems). The variations in the PLF and PHR values are found primarily due to the following two reasons:

(1) Variation in the sugarcane crushing rate, which in turn varied the process steam consumption from the turbine as well as the fuel (bagasse) supply rate to the boiler.

(2) Variation in the demand for power/ electricity from the grid, which in turn varied the PLF.

Thus, in the present study exergy analysis is carried out for various values of PLF and PHR and an attempt is made to find an optimum value for PHR in terms of exergy at different values of PLFs'. The following section deals with process description of the plant followed by the analysis procedure employed.

\section{PROCESS DESCRIPTION OF THE PLANT}

The schematic diagram of the plant is shown in Figure 1. It consists of Boiler, turbine, surface condenser, De-aerator, High pressure heater $(\mathrm{HPH})$, condensate extraction pump (CEP), Boiler feed pump (BFP). The fuel used is bagasse which is a waste product for the sugar industry. The CHP plant is of condensate cum extraction type and is integrated with a sugar mill in order to meet internal power and steam requirements. The excess is exported to the grid. The bagasse as fuel is supplied from the same sugar mill of 5500 TCD (tons of cane crushed per day) capacity. It is generally having a moisture content of $50 \%$. The boiler is travelling grate type. This technology usually has a boiler efficiency based on LHV (Lower Heating value) and requires around 25-30\% excess air. The combustion air is pre-heated in Air pre-heater (APH) to a temperature of $220{ }^{\circ} \mathrm{C}$ using flue gases. This air is admitted into the combustion chamber at state point 16 .

The steam temperature and pressure generated in the boiler depends on the steam turbine specification which in this case is $490 \pm 5^{\circ} \mathrm{C}$ and 64 ata pressure. This boiler operates at a steam /bagasse (S/B) ratio of 2.52. Steam at 9 ata pressures is bled from the turbine at state point 2 which is used as process heat for distillery or ethanol production. Part of the steam is taken from this line to High pressure heater $(\mathrm{HPH})$ in order to increase the temperature of the feed water. Process heat is also extracted at state point 3 for sugar production process at 3 ata. Maximum process heat is drawn from the turbine at state point 3 due to heavy steam demand conditions. The remaining steam goes to the surface condenser. The surface condenser is of shell and tube type utilizing cooling water from forced circulation cooling tower. The saturation temperature of steam entering the condenser is in the range of $42-48{ }^{\circ} \mathrm{C}$. The condenser pressure is at 0.075 bar i.e. under vacuum. Above all the amount of steam condensate collected is dependent on the nature of the production process. If lot of steam is drawn for process at state points $2 \& 3$ then the condensate collected would be quite less. But under any circumstances of operating conditions the condenser is designed for a minimum load of $20 \mathrm{t} / \mathrm{hr}(5.55 \mathrm{~kg} / \mathrm{s})$ and a maximum load of $80 \mathrm{t} / \mathrm{hr}$. The condensate is pumped from the condenser to de-aerator with the help of condensate extraction pump (CEP). The de-aerator is used to degasify boiler feed water in order to minimize corrosion problems. It is a direct contact heat exchanger. Here water is preheated to nearly saturation conditions in order to 
attain zero solubility. This pressurized de-aerator operates at 1.5 bars pressure. Steam needs to be removed from the deaerator along with insoluble and non-condensable gases. This deficit is met out by makeup water at state point 9 . The condensate from the de-aerator is pumped to High pressure heater (HPH) by means of boiler feed pump (BFP). The feed water is pre-heated to a temperature of $145-160{ }^{\circ} \mathrm{C}$ before entering the boiler (i.e. economizer). The plant operates under various PHR (power to heat ratio) values depending on the fluctuations in the demand for process heat and power export. The values of thermodynamic properties at various state points are shown in table 1 (refer Appendix).

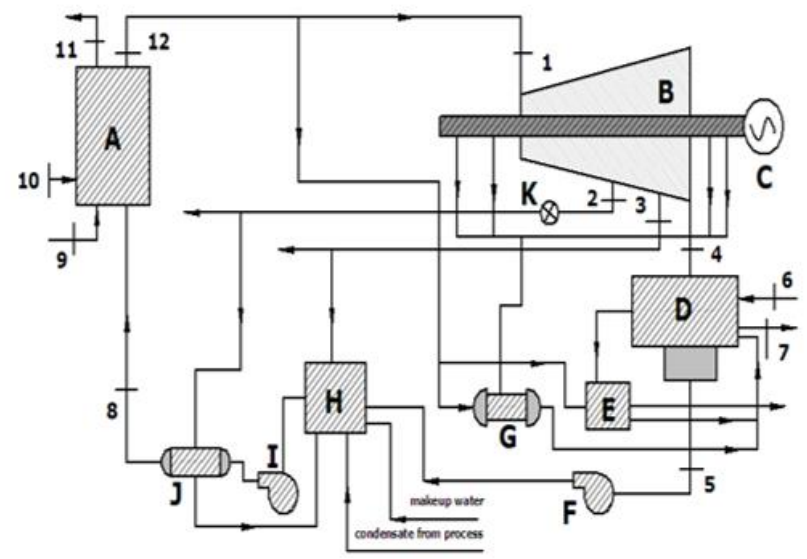

A - boiler; 8 - turbine; $\mathrm{C}-$ generator; 0 - condenser; $\mathrm{E}-$ steam jet air ejector (SJAE); F- condensate extraction pump (CEP) 6- - gland steam conders

Figure 1. Layout of Combined Heat and Power (CHP) plant system

To High pressure heater (HPH) by means of boiler feed pump (BFP). The feed water is pre-heated to a temperature of 145- $160^{\circ} \mathrm{C}$ before entering the boiler (i.e. economizer). The plant operates under various PHR (power to heat ratio) values depending on the fluctuations in the demand for process heat and power export. The values of thermodynamic properties at various state points are shown in Table 1 (refer Appendix).

\section{ANALYSIS}

During past few decades, exergy analysis has been emerged as an important tool for design and optimization of engineering systems. Exergy is generally not conserved as energy but destructed in the system. Thus exergy analysis can be extremely beneficial for bagasse based CHP plant in identifying locations of deviations from ideality. The present work of analysis comprises of mass and exergy balance, exergy destruction, Improvement potential, exergy ratios, exergy efficiency.

\subsection{Mass balance}

The mass balance for steady state steady flow processes is as given below,

$$
\sum m_{\text {in }}=\sum m_{\text {out }}
$$

Suffixes 'in' and 'out' indicate inlet and outlet conditions respectively.

\subsection{Exergy balance}

The general exergy balance equation is given as,

$$
\sum E x_{\text {in }}-\sum E x_{\text {out }}=\sum E x_{\text {Dest }}
$$

Specific flow exergy is given by,

$$
e x=\left(h-h_{0}\right)-T_{0}\left(s-s_{0}\right)
$$

Specific exergy for an incompressible flow is given as [16],

$$
e x_{i n}=C\left[\left(T-T_{0}\right)-T_{0} \ln \frac{T}{T_{0}}\right]
$$

Equation 3 is used for steam flow and equation 4 is used for condensates and feed water flow conditions.

The physical / flow exergy for air and combustion/flue gases is given by [17],

$$
\begin{gathered}
e x_{i n}=C\left[\left(T-T_{0}\right)-T_{0} \ln \frac{T}{T_{0}}+R T_{0} \ln \left[\frac{P}{P_{0}}\right]\right] \\
\operatorname{ex}_{\text {in }}=C\left[\left(T-T_{0}\right)-T_{0} \ln \frac{T}{T_{0}}+\right]
\end{gathered}
$$

The specific heat capacity of air is a function of absolute temperature is given as [18],

$$
C_{\text {air }}=1.04841-\frac{3.83719 T}{10^{4}}+\frac{9.45378 T^{2}}{10^{7}}-\frac{5.4903 T^{3}}{10^{10}}+\frac{7.92981 T^{4}}{10^{14}}
$$

The specific heat of flue/combustion gases liberated by burning bagasse in a boiler is given as [19],

$$
C_{f g}=\left(0.27+.00006 T_{f g}\right)
$$

where $\mathrm{T}_{\mathrm{fg}}$ is temperature of flue gases in ${ }^{\circ} \mathrm{C}$.

The fuel exergy rate is the sum of physical and chemical exergy which is given as,

Fuel exergy rate $=[$ Physical exergy rate of air $]+[$ chemical exergy rate of fuel]

$$
E x_{f}=E x_{p h}+E x_{c h}=m_{a} e x_{a}^{p h}+m_{f} e x_{f}^{c h}
$$

The specific chemical exergy of bagasse is found experimentally [20] as $9890.70 \mathrm{KJ} / \mathrm{kg}$.

\subsection{Exergy destruction}

Applying exergy balance equation 2, the exergy destruction equations are established for all the components of the CHP system as below,

Boiler:

$$
E x_{\text {Dess }, b i}=E x_{f}+E x_{f v}-E x_{f g}-E x_{a s h}
$$




$$
E x_{D e s, b o i}=E x_{16}+E x_{17}+E x_{15}-E x_{18}-E x_{19}-E x_{20}
$$

Turbine:

$$
E x_{D e s, T u r}=E x_{1}-E x_{2}-E x_{3}+E x_{4}-W_{T}
$$

Condenser: The exergy destruction equation for condenser is given as below [21],

$$
\begin{gathered}
E x_{D e s t, \text { Con }}=X_{1}+X_{2}-X_{3} \\
X_{1}=m_{v}\left\{C_{p, v}\left[\left(T_{v 1}-T_{\text {cond }}\right)-T_{0} \ln \left[\frac{T_{v 1}}{T_{\text {cond }}}\right]\right]\right\} \\
X_{2}=m_{v}\left(h_{f g \mid T=T \text { Tond }}-T_{0} S_{f g \mid T=T C o n d}\right)
\end{gathered}
$$

Condensate extraction pump (CEP):

$$
E x_{D e s t, C e p}=E x_{5}+W_{\text {cep }}-E x_{8}
$$

De-aerator:

$$
E \dot{x}_{D e s t, d e i}=E x_{8}+E \dot{x}_{9}+E x_{10}+E \dot{x}_{11}-E x_{12}
$$

Boiler feed pump (BFP):

$$
E x_{D e s t, b f p}=E x_{12}+W_{b f p}-E x_{13}
$$

High pressure heater (HPH):

$$
E x_{d e s t, h p h}=E x_{14}+E x_{13}-E x_{15}-E x_{11}
$$

Now the total exergy destruction taking place in the CHP system is given by,

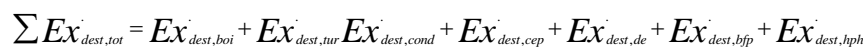

\subsection{Efficiency}

The exergy efficiency of the CHP components and CHP system as a whole is as given below,

$$
\begin{gathered}
\eta_{e x, b o i}=\frac{E x_{19}-E x_{15}}{E x_{f}} \\
\eta_{e x, t u r}=\frac{W_{T}}{E x_{1}-E x_{2}-E x_{3}-E x_{4}}
\end{gathered}
$$

The exergetic efficiency of condenser is as below [21], $\eta_{e x, c c o d}=\frac{m_{c} C_{p, c}\left\{\left[\left(T_{c 2}-T_{c 1}\right)-T_{0} \ln \left[\frac{T_{c 2}}{T_{c 1}}\right]\right]\right\}}{X_{1}+X_{2}}$

$\mathrm{X}_{1}$ and $\mathrm{X}_{2}$ have been defined in equation $11 \mathrm{a}$ and $11 \mathrm{~b}$.

The exergetic efficiency of HPH is given as

$\eta_{e x, H P H}=\frac{E x_{\text {cold, out }}-E x_{\text {cold ,in }}}{E x_{\text {hot }, \text { in }}-E x_{\text {hot, out }}}=\frac{E x_{15}-E x_{13}}{E x_{14}-E x_{11}}$

The exergetic efficiency of CHP system is given by

$\eta_{e x, C H P}=\frac{W_{T}^{\cdot}+E x_{P}}{E x_{f}}=\frac{W_{T}^{\cdot}+E x_{2}+E x_{3}}{E \dot{x}_{f}}$

The waste exergy rates are calculated as,

$$
\sum E x_{w}=E x_{18}+E x_{4}
$$

\subsection{Improvement potential (IP)}

Another useful parameter employed here is the concept of an exergetic improvement potential (IP), which is in the rate form, is below [22],

$$
I P=\left(1-\eta_{e x}\right)\left(E x_{i n}-E x_{\text {out }}\right)
$$

\subsection{Total exergy destruction ratio (TExDR)}

It is described as the ratio of total exergy destruction in the system to the total exergy input to the system as follows [23],

$$
T E x D R=\frac{E x_{T o t, d e s t}}{E x_{T o t, i n}}
$$

\subsection{Component exergy destruction ratio (CExDR)}

It is described as the ratio of exergy destruction of any component of the system to the exergy input to the system as follows [23],

$$
C E x D R=\frac{E x_{i, d e s t}}{E x_{\text {Tot, in }}}
$$

\subsection{Dimensionless exergy destruction ratio (DExDR)}

It is described as the ratio of exergy destruction of any component of the system to the total exergy destruction of the system as follows [23], 


$$
D E x D=\frac{E x_{i, d e s t}}{E x_{\text {Tot,dest }}}
$$

\subsection{Exergetic performance co-efficient (EPC)}

Another important parameter used in the present analysis is the EPC, which is defined as the ratio of the total exergy output from the system to the total exergy destructed in the system. In the present context, the CHP system gives process heat and power as useful exergy outputs, and total exergy destruction is the sum of exergy destructions in the individual components. Mathematically it is defined as [24],

$$
E P C=\frac{E_{T}}{T_{0} s_{g}}=\frac{E \dot{x}_{p}+W_{T}}{\sum E \dot{x}_{\text {Tot,dest }}}=\frac{E x_{2}+E \dot{x}_{3}+W_{T}}{\sum E \dot{x}_{\text {Tot,dest }}}
$$

\subsection{Exergetic factor $(\mathbf{E F})$}

It is defined as the ratio of waste exergy rates and the total exergy input rates as given below:

$$
E F=\frac{\sum E x_{w}}{\sum E x_{T o t, d e s t}}
$$

\subsection{Power to heat ratio (PHR)}

It is defined as the ratio of power generated by the turbine to the process steam supplied. It is given by,

$$
E P C=\frac{W_{T}}{Q_{P}}=\frac{W_{T}}{E_{2}^{\cdot}+E_{3}}
$$

\subsection{Assumptions}

The assumptions made in the present analysis are as follows,

(1) Only physical or flow exergy is taken into account.

(2) The changes in kinetic and potential energies are neglected.

(3) Both Air and products of combustion behave as ideal gas.

(4) The combustion is complete.

(5) Heat loss from the components to the Environment is negligible.

(6) Thermo physical properties of fluids are invariant.

(7) The CHP system operates in a steady state.

(8) The changes in the ambient conditions are neglected.

(9) The reference conditions adopted are $298 \mathrm{~K}$ and 1.0132 bar pressure.

The exergy destroyed in the plant's component is a function of entropy generated and the ambient air temperature surrounding the component. Temperature surrounding the component in a CHP system changes substantially in terms of location. For instance, the temperature of the air surrounding the boiler and condenser, have large variation in the ambient conditions. Hence in the present analysis a naturalenvironment-subsystem model [25] is adopted for the reference condition as stated in the assumptions above.

\section{RESULTS AND DISCUSSION}

Table 2 (refer Appendix) shows the results of exergy analysis of different components and the CHP system as a whole. The highest exergy destruction take place in the boiler followed by turbine and condenser. Condenser is found to be the least efficient component and turbine is the most efficient component of the plant in terms of exergy. Highest IP value exists for boiler followed by turbine and condenser. Boiler has CExDR and DExDR values of 0.6656 and 0.8690 respectively. This indicates that $66.56 \%$ of total exergy input and $86.90 \%$ of total exergy destruction take place in boiler. Turbine has CExDR and DExDR values of 0.0815 and 0.1064 respectively. This indicates that $8.15 \%$ of total exergy input and $10.64 \%$ of total exergy destruction take place in turbine. Condenser has CExDR and DExDR values of 0.0188 and 0.0245 respectively. This indicates that $1.88 \%$ of total exergy input and $2.45 \%$ of total exergy destruction take place in condenser. The TExDR value is 0.7660 . This indicates that $76.60 \%$ of total exergy input got destructed collectively in three major components of CHP system. The exergy efficiency of the CHP system is $20.25 \%$.

Table 3 (refer Appendix) shows the values of exergy rates at different state points with $100 \%$ PLF and variable PHR. The PHR value ranges from 0.6851 to 0.4660 . This shows that the process steam demand increased with constant generator output of $20700 \mathrm{~kW}$. This increased the load on the boiler and in turn the steam flow rate to the turbine. Hence the value of SSC increased from 5.655 to 5.855 . Steam to bagasse ratio increased from 2.33 to 2.40. Table 4 (refer Appendix) shows the results of exergy analysis at $100 \%$ PLF and PHR varying from 0.6851 to 0.4660 . Exergy destruction and IP rates decrease for boiler from PHR value of 0.6851 to 0.4660 . Boiler exergy efficiency increased from $29.62 \%$ to $30.75 \%$. Similar trends can be noticed for exergy destruction and IP rates in turbine and condenser. The exergy efficiency of turbine increased, whereas for condenser it almost remained in the range of $20.63 \%$ to $20.88 \%$. Exergy efficiency of CHP system increased from $20.50 \%$ to $22.96 \%$. The TExDR value decreased from 0.7660 to 0.7440 . This indicates that the CHP system is found to be more sustainable if it is operated with a PHR value of 0.4660 at $100 \%$ PLF. Figure 2 shows variation of TExDR and SSC with PHR values at $100 \%$ PLF. As PHR is decreased below 0.546 , TExDR value decreases below 0.7533 but the value of SSC rises from 5.763 to 5.855 . Hence if the plant is operated at PHR of 0.546 it would be quite balanced in terms of sustainability and the generation cost of electricity. After all electricity/ surplus power export increases the economic viability of the plant. Hence to strike a balance between SSC and TExDR it would be quite advisable to operate the plant with PHR value of 0.546 (approx.) at $100 \%$ PLF.

Table 5 (refer Appendix) shows the values of exergy rates at various state points, with constant PLF of $89.37 \%$ and variable PHR. The PHR values range from 0.3923 to 0.2445 . The SSC ranges from 5.978 to 6.445 . S/B ratio increased from 2.23 to 2.38. An increase in PHR at constant PLF indicates an increase in process steam demand, which in turn increased the load on boiler. Hence steam flow rate to turbine increased with generator output remaining constant at $18500 \mathrm{~kW}$. Similarly, table 6 (refer Appendix) shows the values of exergy rates at various state points, with constant PLF of $75.36 \%$ and variable PHR. 
Figure 2 shows variation of TExDR and SSC with PHR at $100 \%$ PLF. It shows that with an increase in the value of PHR from 0.6851 to 0.466 the value of SSC shows an increasing trend whereas the value of TExDR shows a decreasing trend. Hence to set a trade-off between SSC and TExDR the optimum value of PHR is found to 0.546. Similarly, in figure 3 (at $89.37 \%$ PLF) and figure 4 (at $75.36 \%$ PLF) the optimum values of PHR are found to be 0.2921 and 0.1064 respectively. This shows that as the value of PLF decreases the optimum value of PHR also decreases.

Hence in order to operate the CHP plant on a sustainable basis the value of PHR need to be decreased as the value of PLF decreases.

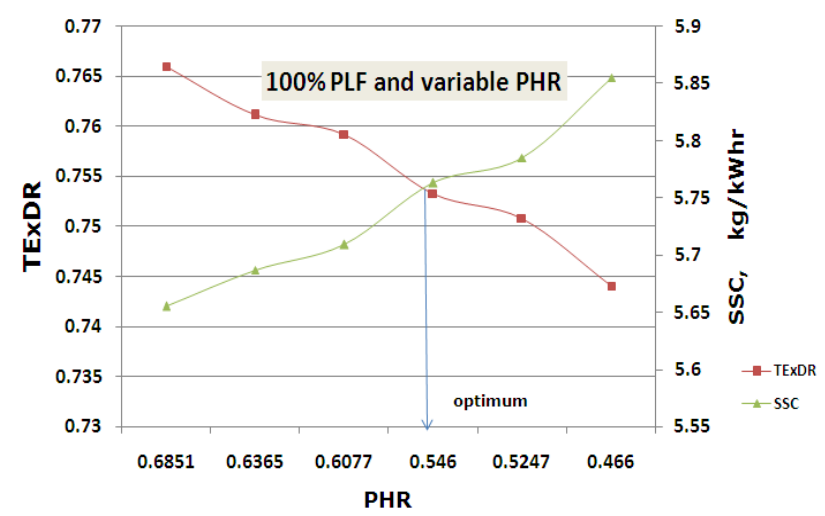

Figure 2. Variation of TExDR and SSC with PHR at $100 \%$ PLF

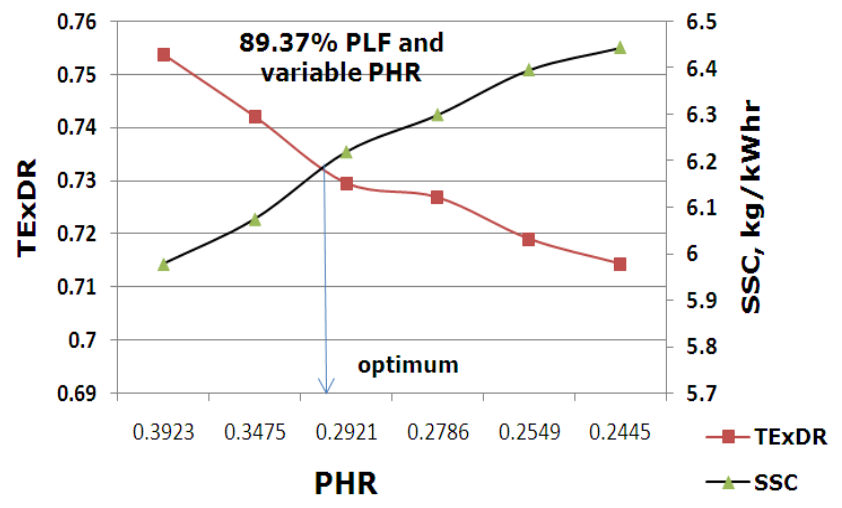

Figure 3. Variation of TExDR and SSC with PHR at $89.37 \%$ PLF

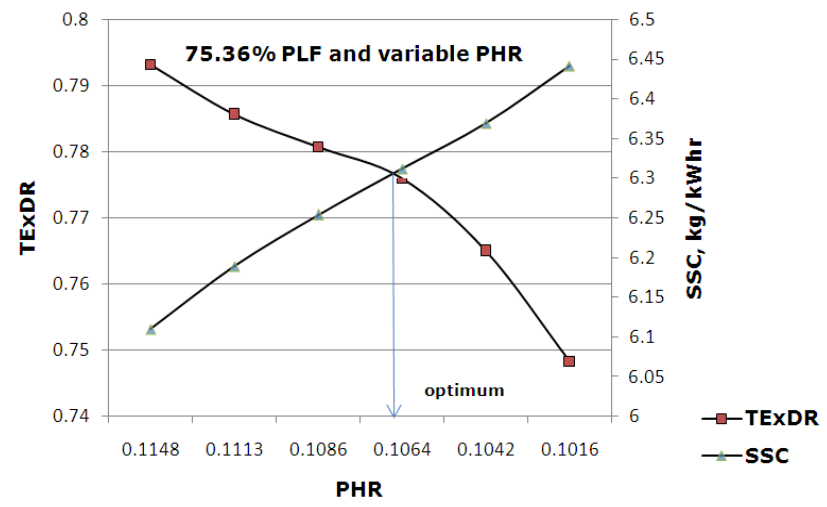

Figure 4. Variation of TExDR and SSC with PHR at $75.36 \% \mathrm{PL}$

\section{CONCLUSIONS}

The following conclusions are drawn from the present analysis:

(1) For all values of PLF the value of SSC increased with an increase in the value of PHR.

(2) For all values of PLF the value of TExDR decreased with an increase in the value of PHR.

(3) For $100 \%$ PLF the optimum value of PHR in terms of TExDR and SSC is 0.546 .

(4) For $89.57 \%$ PLF the optimum value of PHR in terms of TExDR and SSC is 0.2921 .

(5) For $75.36 \%$ PLF the optimum value of PHR in terms of TExDR and SSC is 0.1064 .

(6) For further study in exergy analysis in the field of CHP plants, it is recommended to find the effect of inlet pressure and temperature of steam (at the inlet of the turbine) on exergy efficiency of the plant.

\section{ACKNOWLEDGMENT}

The authors would like to thank the process engineers of the CHP plant for their kind support and compliance in providing the data.

\section{REFERENCES}

[1] Rosen, A.M., Le, N.M., Dincer, I. (2005). Efficiency analysis of cogeneration and district energy systems. Applied Thermal Engineering, 25: 147-159. https://doi.org/10.1016/j.applthermaleng.2004.05.008

[2] Adrian, B. (2002). Fundamentals of exergy analysis, entropy generation minimization and the generation of flow architecture. International Journal of Energy Research, 26: 545-565. https://doi.org/10.1002/er.804

[3] Huang, F.F. (1990). Performance evaluation of selected combustion gas turbine cogeneration systems based on first law and second law analysis. Journal of Engineering for Gas turbines and Power (ASME), 112: 117-121. https://doi.org/10.1115/1.2906465

[4] Bilgen, E. (2000). Exergetic and engineering analysis of gas turbine based cogeneration systems. Energy, 25: 1215-1229. https://doi.org/10.1016/s03605442(00)00041-4

[5] Ozgur, B., Haydar, A. (2007). Energetic and exergetic performance evaluation of a combined heat and power system with micro-gas turbine (MGTCHP). International Journal of Energy Research, 31: 1425-1440. https://doi.org/10.1002/er.1308

[6] Yilmaz, Y., Hikmet, K.T., Arif, H. (2010). Dynamic energy and exergy analyses of an industrial cogeneration system. International Journal of Energy Research, 34: 345-356. https://doi.org/10.1002/er.1561

[7] Aysegul, A., Mehmet, K. (2009). Exergetic and thermoeconomic analyses of diesel engine powered cogeneration: Part 1- Formulations. Applied Thermal Engineering, 29: 234-241. https://doi.org/10.1016/j.applthermaleng.2008.02.025

[8] Aysegul, A., Mehmet, K. (2009). Exergetic and thermoeconomic analyses of diesel engine powered cogeneration: Part 2- Applications. Applied Thermal 
Engineering,

29:

$242-249$

https://doi.org/10.1016/j.applthermaleng.2008.02.026

[9] Aysegul, A., Mehmet, K. (2008). First law and second law analysis of diesel engine powered cogeneration systems. Energy Conversion and Management, 29: 20262031. https://doi.org/10.1016/j.enconman.2008.02.012

[10] Ozgur, B., Haydar, A., Arif, H. (2007). Exergetic performance evaluation of a combined heat and power (CHP) system in Turkey. International Journal of Energy Research, 31: 849-866. https://doi.org/10.1002/er.1353

[11] Siddhartha, B.M., Rajkumar, N. (2001). Mapping of combined heat and power systems in cane sugar industry. Applied Thermal Engineering, 21: 1707-1719. https://doi.org/10.1016/s1359-4311(01)00027-8

[12] Kamate, S.C., Gangawati, P.B. (2009). Exergy analysis of cogeneration power plants in sugar industry. Applied Thermal Engineering, 29: 1187-1194. https://doi.org/10.1016/j.applthermaleng.2008.06.016

[13] Mehmet, K., Ibrahim, D. (2009). Performance assessment of cogeneration plants. Energy Conversion and Management, 50: 76-81. https://doi.org/10.1016/j.enconman.2008.08.029

[14] Sharma, M.P., Sharma, J.D. (1999). Bagasse based cogeneration system for Indian sugar mills. Renewable Energy, 16: 1011-1014. https://doi.org/10.1016/s09601481(98)00356-5

[15] Marc, A.R., Ibrahim, D. (1999). Exergy analysis of waste emissions. International Journal of Energy Research, 23: 1153-1163. https://doi.org/10.1002/(sici)1099. $114 x(19991025) 23: 13 \% 3 C 1153:$ :aider545\%3E3.0.co;2-y

[16] Adrian, B. (1988). Advanced Engineering Thermodynamics. New York: Wiley. https://doi.org/10.1080/03043799808928263

[17] Kotas, T.J. (1995). The Exergy method of Thermal Plant Analysis. (reprint edn), Kieger: Malabar, 288-292. https://doi.org/10.1016/B978-0-408-01350-5.50020-9

[18] Moran, M.J., Shapiro, H.N. (2000). Fundamentals of Engineering Thermodynamics. Wiley: New York. https://doi.org/10.1080/03043799308928176

[19] Hugot, E. (1986). Handbook of Cane sugar Engineering. 3rd edition. Elsevier science publishing company. Amsterdam. https://doi.org/10.1016/b978-1-4832-31907.50016-7

[20] Cortez, C.A.B., Gomez, E.O. (1998). A method for Exergy analysis of sugarcane bagasse boilers. Brazilian Journal of Chemical Engineering, 15: 1-13. https://doi.org/10.1590/s0104-66321998000100006

[21] Haseli, Y., Dincer, I., Naterer, G.F. (2008). Optimum temperatures in a shell and tube condenser with respect to exergy. International Journal of Heat and Mass Transfer, 51: 2462-2470 https://doi.org/10.1016/j.ijheatmasstransfer.2007.08.006

[22] Van, G.W. (1997). Energy policy: fairy tales and factualities. In Innovation and technology- Strategies and policies. Soares, O.D.D., Martins da Cruz, A., Costa Pereira, G., Soares, I.M.R.T., Reis, A.J.P.S. (eds). Kluver: Dordrecht, 93-105. https://doi.org/10.1007/978-0-58529606-7 6.

[23] Coskun, C., Oktay, Z., Dincer, I. (2011). Investigations of some renewable energy and exergy parameters for two Geothermal District Heating systems. International Journal of Exergy, 8: 1-15. https://doi.org/10.1504/IJEX.2011.037211
[24] Ust, Y., Sahin, B., Yilmaz, T. (2007). Optimization of a regenerative gas turbine co-generation system based on a new exergetic performance criterion: Exergetic performance co-efficient. Proceedings of the Institution of Mechanical Engineers Part A: Journal of power and energy, 221: 447-457. https://doi.org/10.1243\%2F09576509JPE379

[25] Ibrahim, D., Marc, A.R. (2007). Exergy: Energy, Environment and sustainable development. First Edition. Elsevier Science Publications: Amsterdam. https://doi.org/10.1016/b978-008044529-8.50006-9

\section{NOMENCLATURE}

$\begin{array}{ll}\text { Nomenclature } \\ \mathrm{C} & \text { Specific heat, }\left(\mathrm{kJ} \mathrm{kg}^{-1} \mathrm{~K}^{-1}\right) \\ \mathrm{E} & \text { Energy kW } \\ \text { ex } & \text { Specific exergy of steam/vapor, }\left(\mathrm{kJ} \mathrm{kg}^{-1}\right) \\ \mathrm{Ex} & \text { Total exergy content, }(\mathrm{kW}) \\ \mathrm{h} & \text { Specific enthalpy, }\left(\mathrm{kJ} \mathrm{kg}^{-1}\right) \\ \mathrm{hfg} & \text { Specific latent enthalpy, }\left(\mathrm{kJ} \mathrm{kg}^{-1}\right) \\ \mathrm{m} & \text { Mass flow rate, }(\mathrm{kg} \mathrm{s}-1) \\ \mathrm{p} & \text { Pressure, (bar) } \\ \mathrm{R} & \text { Particular gas constant }\left(\mathrm{kJ} \mathrm{kg}^{-1} \mathrm{~K}^{-1}\right) \\ \mathrm{s} & \text { Specific entropy }\left(\mathrm{kJ} \mathrm{kg}^{-1} \mathrm{~K}^{-1}\right) \\ \mathrm{sfg} & \text { Specific latent entropy, }\left(\mathrm{kJ} \mathrm{kg}^{-1} \mathrm{~K}^{-1}\right) \\ \mathrm{T} & \text { Temperature }(\mathrm{K}) \\ \mathrm{W} & \text { Work output, }(\mathrm{kW})\end{array}$

\section{Subscripts}

0

$1,2 \ldots .20$

a

air

ash

$\mathrm{C}_{1}$

$\mathrm{C}_{2}$

ch

Cond

Reference state

State points of the system

air

combustion air,

Ash

cooling water Inlet

cooling water outlet

Chemical

dest destruction

f Fuel

fg flue gas

ic incompressible fluid,

in Inlet

out Outlet

$\mathrm{p} \quad$ Process

p,c constant pressure cooling water

$\mathrm{p}, \mathrm{v} \quad$ vapor at constant pressure

ph Physical

pr practical conditions

T Turbine

th theoretical conditions

v1 vapor at inlet

\section{Superscripts}

$\begin{array}{ll}\text { ch } & \text { Chemical } \\ \text { ph } & \text { Physical }\end{array}$

\section{Abbreviations}

$\begin{array}{ll}\mathrm{A} / \mathrm{F} & \text { Air fuel ratio }(\mathrm{kg} \mathrm{kg}-1) \\ \mathrm{APH} & \text { Air pre-heater }\end{array}$




\begin{tabular}{llll} 
BFP & Boiler feed pump & DExDR & Dimensionless exergy destruction ratio \\
Boi & Boiler & EF & Exergetic factor \\
BPST & Back pressure steam turbine & Tur & Turbine \\
CEP & Condensate extraction pump & Greek symbols \\
CExDR & Component exergy destruction ratio & $\eta_{e x}$ & exergy efficiency, \% \\
CHP & Combined heat and power & \multicolumn{2}{l}{}
\end{tabular}

\section{APPENDIX}

Table 1. Thermodynamic properties and Exergy rates at various state points in the CHP system with $100 \%$ PLF and $\mathrm{PHR}=0.6851$

\begin{tabular}{|c|c|c|c|c|c|c|c|c|c|}
\hline $\begin{array}{l}\text { State } \\
\text { point }\end{array}$ & Substance & $\begin{array}{c}m \\
\mathrm{~kg} \mathrm{~s}^{-1}\end{array}$ & $\underset{\text { bar }}{\mathbf{p}}$ & $\begin{array}{c}\mathrm{T} \\
{ }^{0} \mathrm{C}\end{array}$ & $\underset{\mathrm{kj} \mathrm{kg}^{-1} \mathrm{~K}^{-1}}{\mathrm{C}}$ & $\begin{array}{c}\text { h } \\
\mathrm{kj} \mathrm{kg}^{-1}\end{array}$ & $\underset{\mathrm{kj} \mathrm{kg}^{-1} \mathrm{~K}^{-1}}{\mathrm{~S}}$ & $\underset{\mathrm{kj} \mathrm{kg}^{-1}}{\mathrm{ex}}$ & $\begin{array}{l}E x \\
\mathbf{k W}\end{array}$ \\
\hline 1 & Superheated steam & 32.51 & 64.00 & 490 & 2.40 & 3394.43 & 6.81 & 1368.63 & 44494.16 \\
\hline 2 & Process steam & 3.61 & 16.00 & 300 & 2.24 & 3035.43 & 6.88 & 988.77 & 3569.45 \\
\hline 3 & Process steam & 6.94 & 3.00 & 155 & 2.14 & 2771.93 & 7.10 & 659.71 & 4578.38 \\
\hline 4 & Exhaust steam & 21.96 & 0.12 & 50 & 1.94 & 2591.29 & 8.07 & 190.01 & 4172.61 \\
\hline 5 & Condensate & 22.18 & --- & 45 & 4.18 & 188.43 & 0.63 & 2.685 & 59.55 \\
\hline 6 & Cooling water & 1578.00 & 2.48 & 25 & 4.18 & 104.83 & 0.36 & 0.00 & 0.00 \\
\hline 7 & Cooling water & 1578.00 & 1.50 & 33 & 4.17 & & & & 1073.04 \\
\hline 8 & Feed water & 33.38 & ---- & 160 & 4.33 & 675.47 & 1.94 & 102.42 & 3418.77 \\
\hline 9 & Combustion air & 51.94 & 1.07 & 180 & 1.02 & 462.06 & ---- & 35.62 & 1850.10 \\
\hline 10 & Fuel & 14.04 & ---- & --- & ---- & ---- & ---- & 9890.70 & 138865.42 \\
\hline 11 & Flue gas & 64.66 & 2.48 & 155 & 0.28 & 119.84 & ---- & 82.74 & 5350.65 \\
\hline 12 & Superheated steam & 32.73 & 66.00 & 495 & 2.41 & 3404.06 & 6.81 & 1378.26 & 45110.44 \\
\hline
\end{tabular}

Table 2. Results of exergy analysis of different components of CHP system with $100 \%$ PLF and PHR=0.6851

\begin{tabular}{|c|c|c|c|c|c|c|c|}
\hline SI no & particular & $\begin{array}{c}E x_{\text {dest }} \\
\mathbf{k W}\end{array}$ & $\begin{array}{c}\eta_{e x} \\
\%\end{array}$ & $\begin{array}{l}\text { IP } \\
\mathrm{kW}\end{array}$ & CExDR & TExDR & DExDR \\
\hline 01 & Boiler & 93673.20 & 29.62 & 65297.19 & 0.6656 & & 0.8690 \\
\hline 02 & Turbine & 11473.72 & 64.33 & 4092.67 & 0.0815 & & 0.1064 \\
\hline 03 & Condenser & 2647.72 & 20.81 & 2096.23 & 0.0188 & 0.7660 & 0.0245 \\
\hline 06 & Total/ Avg & 107794.02 & 38.25 & 71486.09 & & & \\
\hline 07 & $\dot{E} x_{i n} \mathrm{~kW}$ & \multicolumn{6}{|c|}{140715.52} \\
\hline 08 & $\eta_{e x, C H P}$ & \multicolumn{6}{|c|}{20.50} \\
\hline
\end{tabular}

Table 3. Exergy rates at different state points at $100 \%$ PLF and various values of PHR

\begin{tabular}{c|cccccc}
\hline PLF, \% & \multicolumn{7}{|c}{100} \\
\hline PHR & 0.6851 & 0.6365 & 0.6077 & 0.5460 & 0.5247 & 0.4660 \\
SSC, kg kWhr & 5.655 & 5.687 & 5.709 & 5.763 & 5.785 & 5.855 \\
S/B & 2.33 & 2.36 & 2.37 & 2.37 & 2.38 & 2.40 \\
State point & $\mathrm{Ex}, \mathrm{kW}$ & $\mathrm{Ex}, \mathrm{kW}$ & $\mathrm{Ex}, \mathrm{kW}$ & $\mathrm{Ex}, \mathrm{kW}$ & $\mathrm{Ex}, \mathrm{kW}$ & $\mathrm{Ex}, \mathrm{kW}$ \\
$\mathbf{1}$ & 44494.16 & 44754.20 & 44932.12 & 45356.39 & 45520.63 & 46068.08 \\
$\mathbf{2}$ & 3569.45 & 3569.45 & 3569.45 & 3569.45 & 3569.45 & 3569.45 \\
$\mathbf{3}$ & 4578.38 & 5125.94 & 5495.38 & 6412.38 & 6780.35 & 7949.50 \\
$\mathbf{4}$ & 4172.61 & 4051.01 & 3969.30 & 3764.09 & 3682.39 & 3420.18 \\
$\mathbf{5}$ & 59.55 & 57.83 & 56.68 & 53.78 & 52.62 & 48.92 \\
$\mathbf{6}$ & 0.00 & 0.00 & 0.00 & 0.00 & 0.00 & 0.00 \\
$\mathbf{7}$ & 1073.04 & 1043.12 & 1022.72 & 970.36 & 938.86 & 882.67 \\
$\mathbf{8}$ & 3418.77 & 3428.23 & 3452.57 & 3484.32 & 3497.60 & 3539.38 \\
$\mathbf{9}$ & 1850.10 & 1836.92 & 1837.63 & 1847.25 & 1838.34 & 1851.70 \\
$\mathbf{1 0}$ & 138865.42 & 137876.35 & 137876.35 & 138055.96 & 137975.26 & 139044.36 \\
$\mathbf{1 1}$ & 5350.65 & 5311.90 & 5315.56 & 5336.86 & 5315.94 & 5354.05 \\
$\mathbf{1 2}$ & 45110.44 & 45372.32 & 45551.49 & 45978.75 & 46144.14 & 46695.44 \\
\hline
\end{tabular}


Table 4. Results of exergy analysis at $100 \%$ PLF and various values of PHR

\begin{tabular}{|c|c|c|c|c|c|c|}
\hline \multirow{4}{*}{$\begin{array}{c}\text { PLF,\% } \\
\text { Generator output, kW } \\
\text { PHR } \\
\text { SSC kg kWhr }{ }^{-1}\end{array}$} & \multicolumn{6}{|c|}{100} \\
\hline & \multicolumn{6}{|c|}{20700} \\
\hline & 0.6851 & 0.6365 & 0.6077 & 0.5460 & 0.5247 & 0.4660 \\
\hline & 5.655 & 5.687 & 5.709 & 5.763 & 5.785 & 5.855 \\
\hline$E x_{d e s t, b o i}, \mathbf{k W}$ & 93673.20 & 92467.28 & 92335.50 & 92071.92 & 91851.12 & 91811.39 \\
\hline$\dot{E} x_{\text {dest,tur }}, \mathbf{k} \mathbf{W}$ & 11473.72 & 11307.80 & 11198.01 & 10910.47 & 10788.44 & 10428.95 \\
\hline$\dot{E} x_{\text {dest,cond }}, \mathbf{k W}$ & 2647.10 & 2569.20 & 2550.46 & 2420.00 & 2341.33 & 2167.85 \\
\hline$\dot{E} x_{d e s t, t o t}, \mathbf{k W}$ & 107794.02 & 106344.28 & 106083.97 & 105402.39 & 104980.89 & 104408.19 \\
\hline$\dot{E} x_{i n}=\dot{E} x_{15}+\dot{E} x_{16}, \mathbf{k W}$ & 140715.52 & 139712.35 & 139713.98 & 139903.21 & 139813.60 & 140321.50 \\
\hline TExDR & 0.7660 & 0.7611 & 0.7592 & 0.7533 & 0.7508 & 0.7440 \\
\hline$\eta_{e x, b o i}, \%$ & 29.62 & 30.01 & 30.10 & 30.37 & 30.50 & 30.75 \\
\hline$\eta_{e x, t u r}, \%$ & 64.33 & 64.67 & 64.89 & 65.48 & 65.73 & 66.49 \\
\hline$\eta_{\text {ex,cond }}, \%$ & 20.81 & 20.83 & 20.63 & 20.63 & 20.63 & 20.88 \\
\hline$I P_{b o i}, \mathbf{k W}$ & 65927.19 & 64717.84 & 64542.51 & 64109.67 & 63836.52 & 63579.38 \\
\hline$I P_{t u r}, \mathbf{k W}$ & 4092.67 & 3995.04 & 3931.62 & 3766.29 & 3697.19 & 3494.74 \\
\hline$I_{\text {cond }}, \mathbf{k W}$ & 2096.23 & 2034.03 & 2024.30 & 1920.75 & 1858.31 & 1715.20 \\
\hline$\eta_{e x, C H P}, \%$ & 20.50 & 21.03 & 21.30 & 21.93 & 22.20 & 22.96 \\
\hline
\end{tabular}

Table 5. Exergy rates at different state points at $89.37 \%$ PLF and various values of PHR

\begin{tabular}{c|cccccc}
\hline PLF, \% & \multicolumn{7}{|c}{89.37} \\
\hline PHR & 0.3923 & 0.3475 & 0.2921 & 0.2786 & 0.2549 & 0.2445 \\
SSC, kg kWhr & 5.978 & 6.075 & 6.220 & 6.300 & 6.397 & 6.445 \\
S/B & 2.23 & 2.29 & 2.31 & 2.33 & 2.36 & 2.38 \\
State point & Ex, kW & $E x, \mathrm{~kW}$ & $\mathrm{Ex}, \mathrm{kW}$ & $\mathrm{Ex}, \mathrm{kW}$ & $\mathrm{Ex}, \mathrm{kW}$ & $\mathrm{Ex}, \mathrm{kW}$ \\
$\mathbf{1}$ & 42044.31 & 42728.62 & 43755.10 & 44302.55 & 44986.86 & 45329.02 \\
$\mathbf{2}$ & 3292.60 & 3292.60 & 3569.45 & 3292.60 & 3292.60 & 3292.60 \\
$\mathbf{3}$ & 8793.93 & 10258.49 & 12455.32 & 13194.20 & 14658.75 & 15391.03 \\
$\mathbf{4}$ & 2671.54 & 2344.72 & 1801.29 & 1717.69 & 1390.87 & 1227.46 \\
$\mathbf{5}$ & 38.34 & 33.72 & 26.04 & 24.86 & 20.24 & 17.93 \\
$\mathbf{6}$ & 0.00 & 0.00 & 0.00 & 0.00 & 0.00 & 0.00 \\
$\mathbf{7}$ & 687.01 & 602.96 & 463.22 & 441.72 & 357.68 & 315.65 \\
$\mathbf{8}$ & 3231.35 & 3283.58 & 3362.44 & 3404.44 & 3456.67 & 3482.28 \\
$\mathbf{9}$ & 1827.66 & 1808.07 & 1835.85 & 1842.26 & 1847.60 & 1845.11 \\
$\mathbf{1 0}$ & 137184.00 & 135700.40 & 137777.45 & 138271.98 & 138667.61 & 138469.80 \\
$\mathbf{1 1}$ & 5284.60 & 5228.34 & 5306.94 & 5436.01 & 5342.52 & 5335.07 \\
$\mathbf{1 2}$ & 42643.36 & 43332.49 & 44366.18 & 44917.49 & 4560.62 & 45951.18 \\
\hline
\end{tabular}

Table 6. Exergy rates at different state points at $75.36 \%$ PLF and various values of PHR.

\begin{tabular}{|c|c|c|c|c|c|c|}
\hline PLF, \% & \multicolumn{6}{|c|}{75.36} \\
\hline PHR & 0.1148 & 0.1113 & 0.1086 & 0.1064 & 0.1042 & 0.1016 \\
\hline SSC, kg kWhr-1 & 6.110 & 6.189 & 6.254 & 6.312 & 6.369 & 6.441 \\
\hline $\mathbf{S} / \mathbf{B}$ & 1.76 & 1.80 & 1.82 & 1.84 & 1.92 & 2.05 \\
\hline State point & $\mathrm{Ex}, \mathrm{kW}$ & Ex, kW & Ex, kW & Ex, kW & Ex, kW & Ex, kW \\
\hline 1 & 36227.63 & 36706.65 & 37089.87 & 37432.03 & 37774.18 & 38198.46 \\
\hline 2 & 3292.60 & 3292.60 & 3292.60 & 3292.60 & 3292.60 & 3292.60 \\
\hline 3 & 8264.37 & 9249.13 & 10073.77 & 10806.04 & 11544.92 & 12455.32 \\
\hline 4 & 2021.70 & 1799.39 & 1615.08 & 1451.67 & 1286.36 & 1083.05 \\
\hline 5 & 29.159 & 26.01 & 23.41 & 21.10 & 18.76 & 15.89 \\
\hline 6 & 0.00 & 0.00 & 0.00 & 0.00 & 0.00 & 0.00 \\
\hline 8 & 2787.87 & 2824.74 & 2853.42 & 2880.05 & 2905.65 & 2938.42 \\
\hline 9 & 1997.92 & 1979.40 & 1977.97 & 1974.06 & 1908.16 & 1808.07 \\
\hline 10 & 149943.01 & 148558.31 & 148459.40 & 148162.68 & 143217.33 & 135700.40 \\
\hline 11 & 5776.90 & 5723.12 & 5718.98 & 5708.23 & 5517.10 & 5228.34 \\
\hline 12 & 36785.75 & 37268.15 & 37654.06 & 37998.62 & 38343.19 & 38770.45 \\
\hline
\end{tabular}

